\title{
The First Step to Leadership in School Management: Taking Initiative
}

\author{
İlknur Şentürk \\ Additional information is available at the end of the chapter \\ http://dx.doi.org/10.5772/intechopen.70789
}

\begin{abstract}
Problem statement: The present study aims to determine the situations and the characteristics of these situations, in which school administrators take initiatives, and the outcomes of these initiatives for the school.

Aim of the study: The aim of this study is to investigate school administrators' use of initiative. Consistent with this purpose, conditions and frequencies of school administrators encountering with unordinary situations, references and strategies they apply when there is a complication without formal solution, conditions of taking initiative instead of over-validating the legislation, principles, values, ethical outlines and outcomes of taking initiative are intended to be identified.
\end{abstract}

Methodology: This study aims to identify the conditions of taking initiative, characteristics of these conditions and outcomes of the cases where school administrators take initiative based on interviews.

Results: Initiative domains of school administrators participated in this study bare very limited contribution to lead changes in daily routines and bureaucratic procedures. When legislations and regulations fall short, participating school administrators seem to feel worried, anxious, conflicted, helpless, distrustful and worried about being aggrieved and going under investigation. While taking initiative, principles and values school administrators take into account can be summarized as common interest, institutional benefit, justness, objectivity, and human-orientation.

Keywords: initiative, taking initiative, school administration, school administrators, qualitative study

\section{Introduction}

Origins of organizational and administrative complications in Turkish educational system are mainly rooted in the centralized organizational structure of the state, which is positioned 
behind authoritarian and hierarchical power fields of administrative practices and processes. Modern democratic administration approaches on the other hand prioritize effectuation, leadership, prudential rationality, and willpower. Arranging and implementing decision-making mechanisms are a prerequisite for flexible and democratic organizations and administrations.

Decision-making procedures in educational organizations of Turkish educational system take shape with a centralist conception and lack of pluralistic and efficient participation of stakeholders. Şişman and Turan [1] argue that decentralization and democratization efforts led to greater levels of authority in schools. This in turn led to participation in decision-making processes and school-based management. Principals taking initiative can be considered as a first step toward school-based management. Initiative is defined as the ability to assess and initiate things independently and an act or strategy intended to resolve a difficulty or improve a situation, a fresh approach to a situation [2]. Initiative can also mean a plan that is targeted at solving a particular problem. It also means independent evaluation and ability to act, power to make an attempt, a behavior to overcome a difficulty or to develop a situation further, or a strategy in different languages [3]. Decision-making in an administrative process is a primary factor for determining to what extent it is democratic and autocratic. For school administrators, the extent of taking initiative on school matters is a key to more flexible, humanitarian, and creative institutional processes. Beyond the bulkiness of centralized administration, initiativetaking school administrators would indeed render these processes more effective and efficient.

Personal initiative can be considered as a concept which can contribute to popular debate and research such as leadership, modern management paradigms, decentralization, schoolbased management, school improvement, and exercise and transfer of authority [3-10]. Initiative can be described as self-starting volition of active decision-making and actualization in order to accomplish organizational objectives and overcome organizational challenges [7-9, 11, 12]. To an individual extent, initiative represents a lifestyle. It is related to intelligence, contributing to a certain profession; will of control on situations; exhibition of an active and positive attitude instead of passivity; and hence cultural descriptors of lifestyle $[7,8]$. Quality of work life has been criticized with the remoteness of authority, which is explained as the power distance between the superior and the subordinate.

The concept of decision-making styles is related to the level of contribution of subordinates in decisions, and the extent of power distance in this context is a sign of centralization. There is a demand for an authoritarian leadership in organizations when power distance is large, and in such organizations, active control, low levels of job satisfaction, and fear of change in organizational structures are observed. Workforce is in constant need of orders [3, 13]. Accordingly, remoteness of the authority has to be reduced to pave the way for initiative in organizational models and administrative approaches.

In conditions where there is dense competition of powers, centralized and hierarchical organization structures, employees are expected to be more obedient to the authority and adopt an understanding of order-based conduct and not to exceed their well-defined limits. Initiative on the other hand is a potential facilitator to revoke such orthodoxy of management models. Beyond individual way of behavior, taking initiative is an organizational 
behavior. It requires being in compliance with the objectives of the organization, such as action- and strategy-oriented thinking, a vision, a long-term perspective, consistency, and commitment [14-16]. Aypay and Şekerci [17] indicated that initiative-taking behavior includes listening, human relations, motivating others, conflict management, and personal adaptability. Similarly, Goerdel [18] argued that administrators who take initiative were able to establish an interactive and holistic organizational structure since they grasp actions well. The logic behind initiative is to look out for the interests of the organization, instead of personal benefits. Indeed, interests of the school were the basis emphasized by the administrators during interviews. In the essence of initiative taking lies the ability to solve problems, the capacity for solving problems, creativity and innovation, courage, insight, intuition, and leadership skills. Initiative is the next door just beyond the leadership [19]. Problem solving skills are prerequisites for taking initiative. Ability of coping with challenges brought by administrative roles and responsibilities defines systematic and methodological thinking, proposing solutions and alternatives, thinking in reference to rich and deep sources and to proceed actively [14, 20,21]. The use of initiative requires the ability to predict future situations. Features increasing the potential to take initiative are desire for innovation and working, openness to communication and suggestions, will of doing something without any driving force or supervision, desire to help others and take responsibility, adaptation to teamwork, and willingness to learn. Taking initiative may be dependent upon not only intraorganizational but also external stimuli of social origin. The use of initiative characteristics may vary with motivational levels. Indeed, taking initiative requires certain characteristics. When personal characteristics are considered, setting high personal and organizational standards [5, 22] and initiating task-oriented activities are primary characteristics.

Individual competencies such as proficiency in self-control, effective assessment and supervision ability, self-efficacy and a positive sense of self, being responsible, being open to change, risk and crisis management, and strategic thinking to overcome problems are other characteristics of administrators in the use of initiative. Taking initiative is a characteristic of people with high achievement motivation. However, the nature of the work and possible consequences are generally influential on the use of initiative. It may be described as a form of competency possessed by individuals with high cognitive levels and with an ability to comprehend the characteristics of the work, structure of the organization, and managerial processes in the organization. Organizational climate and culture [23] are also important factors in initiative. Qualifications of an administrator who is likely to be transformation oriented are curiosity, open-mindedness, being away from conventional ways of thinking, ability to manage learning processes and communication patterns, ability in the effective and efficient use of time, extending the realm of freedom, creative thinking, and sustaining high-order targets.

Hence, initiative is a form of thinking and acting that is revealed in the presence of such personal characteristics. Apart from personal characteristics mentioned above, organizational sense of belonging, commitment, and adaptability are also psychological engagements with potential effects on initiative [3]. One of the most important results of initiative taking is 
autonomy. Ambos et al. [24], in their structural equation modeling study, found that taking initiative influences institutional autonomy positively. Taking initiative as a primary focus of administrative processes, functional autonomy, organizational change, execution of organizational behavior beyond predefined roles and responsibilities, strengthening personnel, and transfer of authority will possibly accelerate the expected structural shift, especially in educational organizations [12, 25-29]. Recent studies, which proposed that school education and administration require reconsideration of concepts like autonomy, responsibility, accountability, and effectiveness, advocate that these key concepts could make a reformist change in public schools [14]. Taking initiative, at this very point, emphasizes personal and professional competencies of school administrators for such reformist expectations of change. Demand on organizational and administrational change in educational organizations is of greater concern recently.

Current legal definitions of educational administrators' authority and responsibilities are insufficient for efficient and effective actions against administrative complications they often face. Consequently, hierarchically defined roles that are tied to bureaucratic mechanisms and centralized approaches have been hindering the perception of schools as an agent of change in the social structure. Studies on taking initiative have recently been emphasizing changing paradigms especially on school improvement, school-based administration, and reforming schools in an information society. Possessing similar opportunities and under similar restrictions, what make a world of difference, are leadership traits of administrators. Capitalizing the conditions of school, exploring resources of the institution, and enhancing academic and organizational performance are the outcomes of an effective leadership. Taking initiative may be regarded as a vital first step for an effective leadership. Finally, concepts such as entrepreneurship, creating alternatives, organizational citizenship, and organizational identification that appear frequently in recent literature on administration and organization emphasize the importance of taking initiative. Taking initiative emerges an important personal characteristic for educational administrators since it helps to activate the cultural dynamics of democracy in educational organizations.

The objective of this study is to investigate school administrators' use of initiative. Consistent with this objective, it also aims to identify the conditions and frequencies of school administrators' encounters with unordinary situations, references, and strategies they apply when there is a complication without formal solution, conditions under which they take initiative instead of over-validating the legislation, principles, values, ethical outlines, and outcomes of taking initiative.

Thus, the sub-objectives of the research were determined as follows:

1. Do school administrators experience any situations not explained by legislation and regulations?

2. Under the circumstances where legal texts, legislation and regulations are unable to explain or are not enough, which strategies do school administrators use? 
3. Do school administrators use initiative as an alternative to validate and adhere to the legislation and regulations strictly much more?

4. What are school administrator's principles, values, rules and ethical frame in their initiative process?

5. What are the results of the situations in which school administrators took initiative?

\section{Method}

This study aims to identify the conditions of taking initiative, characteristics of these conditions and outcomes of the conditions where an initiative was taken by school administrators based on conducted interviews. The study group included voluntary school administrators working in Eskişehir province, Turkey. Purposive sampling was used in the study.

\subsection{Research model}

The present research, which aimed to define school administrators' opinions about the situations and results of taking the initiative on decision-making, was designed as a case study (single case study), one of the qualitative research methods. A case study, which is conducted with description and investigation of a restricted system, is a type of qualitative study. In a case study, an up-to-date phenomenon is generally investigated in real-life context. The object of investigation in the present study is a restricted system. A restricted system is where the investigated object is just a person, a program, a group, an institution, a society, or a special policy. In a case study, researcher defines the interaction of significant factors related to that phenomenon by focusing on the phenomenon. The model in which the researcher explores the restricted situation using the data in depth and reports it by describing the themes about this situation is an approach [30-32]. In the present study, the situation is thoughts created by the regulations concerning the appointment of school administrators. In other words, unit of analysis in the case is opinions of school administrators concerning the use of initiative-taking situations.

\subsection{Data collection tool}

Interview technique is the method where the interviewer and interviewee take part by focusing on the questions about the area of research [30]. Interview is a type of interaction [32]. Interview is a technique that is effective in defining behavior, feelings, and expressions, which are not observed [30]. For this reason, in the study, the interview method was used as a data collection tool to observe the change school administrators' views and thoughts about conditions, reasons, and results of taking initiative in the administrative processes. The questions in the semi-constructed form were constituted using flexible expressions to collect personal data. The questions in the interview form were created to focus on topics that were expected to be explained. 


\subsection{Data analysis}

After the interviews were recorded elaborately, the collected data was encoded to determine the identified concepts and expressions and evoked by the research questions and subquestions. Interview details were indexed and categorized by reading the manuscript line by line [32]. On the categorization, theoretical perspective was used. As the data were read, the concepts and words that data evoked and indicated were noted down on the side sections. It was detected that the codes emerged were located in correct frames under the suitable topics and connected to themes created in subproblems of the research. Content analysis was used for data analysis in the current study. The principal objective in content analysis is to collect similar data within the frame of specific concepts and themes and to comment those by arranging the data in a manner that readers could understand ([33], p. 227).

The research is structured in five steps: (i) development of the interview questions, (ii) data collection, (iii) data analysis, (iv) validity and reliability assessment, and (v) interpretation of the data. Development of the data collection tool: At this step of the research, interview form was developed. The "school administrator and initiative" form was utilized to collect data. Interview form was developed by the authors, and in order to provide content validity, five academicians were requested to review the form, and it was finalized based on their suggestions. Data collection: School administrators participated in the study were selected from conveniently available volunteering administrators in the city. Semi-structured questions were asked to the participants, and whenever required, probing questions were used to ease the interview to focus on the details. Data analysis: In order to assess the obtained data, content analysis method was used. Data were coded with elemental structural coding method, which is one of the qualitative data coding methods. As a result, a direct and integrative relationship was aimed to be constituted within the general structure of the content of the study. Validity and reliability: In order to obtain validity of the findings, data analysis procedure was explained in brief, and all utilized codes, which were used to generate categories, were provided. Moreover, direct citations from the interview transcripts were used to achieve validity [34].

In order to assess the reliability of the research, expert opinion was requested to confirm code representations, which were organized in the form of separate themes in the category they were assigned. Expert consensus was obtained, and the categories formed by the authors were compared, and a number of agreements and disagreements were established. Reliability of the research was calculated by using the formula (reliability = number of agreements/number of agreements + disagreements) by Miles and Huberman [35]. The reliability $=106 /(106+8)=0.92$ was calculated using the abovementioned formula.

\subsection{Study group: study participants}

\subsubsection{Characteristics of the workgroup}

\section{See Table 1.}




\begin{tabular}{|c|c|c|c|c|}
\hline Gender & Age & $\begin{array}{l}\text { Experience } \\
\text { (years) }\end{array}$ & Educational background & $\begin{array}{l}\text { Socioeconomic status of } \\
\text { neighborhood worked }\end{array}$ \\
\hline G1: male & 47 & 23 & MA (Educational Administration) & Middle class \\
\hline G2: male & 40 & 17 & MA (Educational Administration) & Middle class + \\
\hline G3: male & 46 & 21 & $\begin{array}{l}\text { Bachelor's degree (primary school } \\
\text { teaching) }\end{array}$ & Low \\
\hline G4: male & 42 & 18 & MA (Educational Administration) & Low \\
\hline G5: male & 49 & 26 & Bachelor's degree (Physics) & Middle class \\
\hline G6: female & 34 & 12 & Bachelor's degree (Chemistry) & Low \\
\hline G7: male & 42 & 18 & Bachelor's degree (Physics) & Middle class + \\
\hline G8: male & 48 & 25 & $\begin{array}{l}\text { Bachelor's degree (Moral and Religious } \\
\text { Ed.) }\end{array}$ & Low \\
\hline G9: male & 33 & 11 & $\begin{array}{l}\text { Bachelor's degree (primary school } \\
\text { teaching) }\end{array}$ & Middle class + \\
\hline G10: male & 40 & 18 & $\begin{array}{l}\text { Bachelor's degree (primary school } \\
\text { teaching) }\end{array}$ & Middle class \\
\hline G11: male & 39 & 14 & $\begin{array}{l}\text { Bachelor's degree (primary school } \\
\text { teaching) }\end{array}$ & Low \\
\hline G12: male & 47 & 20 & Bachelor's degree (Agriculture) & Middle class \\
\hline G13: male & 34 & 12 & MS (Educational Administration) & Middle class \\
\hline G14: male & 41 & 17 & Bachelor's degree (Geography) & Middle class \\
\hline G15: male & 43 & 19 & Bachelor's degree (History) & Low \\
\hline G16: male & 34 & 10 & $\begin{array}{l}\text { Bachelor's degree (Finance and } \\
\text { Accounting) }\end{array}$ & Middle class \\
\hline G17: male & 49 & 25 & Bachelor's degree & Middle class \\
\hline G18: male & 48 & 22 & MA (Educational Administration) & Low \\
\hline G19: male & 37 & 12 & $\begin{array}{l}\text { Bachelor's degree (primary school } \\
\text { teaching) }\end{array}$ & Middle class \\
\hline G20: male & 34 & 11 & $\begin{array}{l}\text { Bachelor's degree (primary school } \\
\text { teaching) }\end{array}$ & Low \\
\hline G21: male & 47 & 21 & Bachelor's degree (Biology) & Middle class + \\
\hline G22: male & 33 & 10 & Bachelor's degree (Physics) & Middle class \\
\hline G23: male & 38 & 14 & $\begin{array}{l}\text { Bachelor's degree (primary school } \\
\text { teaching) }\end{array}$ & Low \\
\hline G24: male & 45 & 22 & $\begin{array}{l}\text { Bachelor's degree (primary school } \\
\text { teaching) }\end{array}$ & Middle class \\
\hline G25: male & 44 & 20 & $\begin{array}{l}\text { Bachelor's degree (primary school } \\
\text { teaching) }\end{array}$ & Middle class \\
\hline G26: male & 46 & 24 & $\begin{array}{l}\text { Bachelor's degree (primary school } \\
\text { teaching) }\end{array}$ & Low \\
\hline G27: male & 38 & 15 & $\begin{array}{l}\text { Bachelor's degree (primary school } \\
\text { teaching) }\end{array}$ & Middle class \\
\hline
\end{tabular}

Table 1. Characteristics of the workgroup. 


\section{Findings}

This section provides findings based on research questions.

\subsection{Findings about the conditions that school administrators take initiative}

Examination of the codes in Table 2 demonstrated that the conditions where school administrators take the initiative seem to concentrate on cases of uncertain expectations of local authorities, personal affairs, physical and financial matters, student affairs and monitoring works, etc. It could be concluded that school administrators do not tend to take initiative in potential fields of improving leadership traits.

S.A 12: "Since there are no legislations and regulations to guide our institution, we are ruled by directives which cause omissions. Therefore, I have trouble and use initiative in course schedules, content confusions, overtime payments, working hours etc."

S.A 15: "When I first appointed as an administrator to X school, I went to district national education directorate to start to work. After introducing myself, I explained that I was there to get started. The Director told me that I should go start myself. I found the situation funny that I should appoint myself. I asked the director if the situation was not weird. He insisted and I did not press any further. At the end, I searched the regulations myself and failed to end up with an answer. First time I took initiative was to appoint myself. That is the initiative I remember the most."

\section{Conditions that school administrators use initiative}

Personnel affairs

Uncertainties in official letters received from the Ministry of Education

Social and cultural activities

Interinstitutional corporations

Assignments of teachers

Urgent extraordinary situations at school

Health excuses of teachers

Planning extra class hours

Human relations

In response to requests of ministries other than the Ministry of Education

Construction and renovation works at school

Financial issues

Off days of teachers

Definition and application of school rules

Employees' personal rights

Curriculum content design

Absenteeism of students

Table 2. Conditions that school administrators take initiative. 


\subsection{Findings about the views of school administrators on legislations falling short}

As a result of the examination of the codes in Table 3, it could be concluded that when legislations and regulations fall short, school administrators seem to think that there are shortages of definitions in legislations, unable to offer alternatives; to doubt the adequacy of people who design legislations; and to think that the challenges they come across are generalized in public administration, etc.

Another finding was the fact that school administrators expect the legislations to include clear and logical definitions of their responsibilities. Sample statements on this issue are given below.

S.A 26: "Sometimes I feel like whoever wrote this on the legislation is out of this world. These statements have nothing to do with the real world. Then when I try sort things out, it is never appreciated. No one cares if the situation is resolved"

S.A. 18: "To be honest, I consult the assistant managers first. If we still cannot work it out, then I consult other administrator friends. I consult my dear friends who are administrators...."

\subsection{Findings about the feelings of school administrators when legislations fall short}

By examining the codes in Table 4, it could be concluded that when legislations and regulations fall short, school administrators seem to feel anxious, conflicted, helpless, distrustful, and worried about hurting their personnel.

Sample statements related to abovementioned findings are as follows:

SA15: "... Although I am sure that I am doing what is right for students by paying extra hours to more than one teacher, I, as a responsible person still feel worried about aggrieving the staff caused by inadequacy of the regulations."

SA21: "...I I do not panic. I take it normal when the regulations fall short."

SA1: “.. I do not remember panicking. Legislative texts are ambiguous. They change quite often though..."

SA18: "...I feel distrust and anxious thinking what investigation would I face because of my decisions. More initiative means more risk and yellow envelope in our system..."

\subsection{Findings about the sources of references and strategies during the decision-making process by taking initiative}

Table 5 presents the codes for reference sources for school administrators' initiative-taken actions. Accordingly, reference sources quoted by school administrators represent efforts they make to reach to the related people, written documents and application examples. It can be asserted that interviewed school administrators exhibit multidimensional efforts to find out solutions to conditions that require initiative. Sample statements made by school administrators evidencing this can be exemplified as follows:

SA4: “... Consulting experienced administrators or superiors is my primary strategy. However, if it is still not enough, I try making reasonable and explainable decisions by obtaining stakeholders' views"

SA9: "As I earlier mentioned, elementary school inspectors and experienced school administrators are my reference sources. Sometimes I add teachers to the decision-making process to share responsibility. And sometimes there are sample court verdicts available. For instance, a newly assigned teacher started working in January and requested stationery payment which is normally paid in September. I looked for a sample court verdict on the Internet and found one. I made the payment accordingly." 


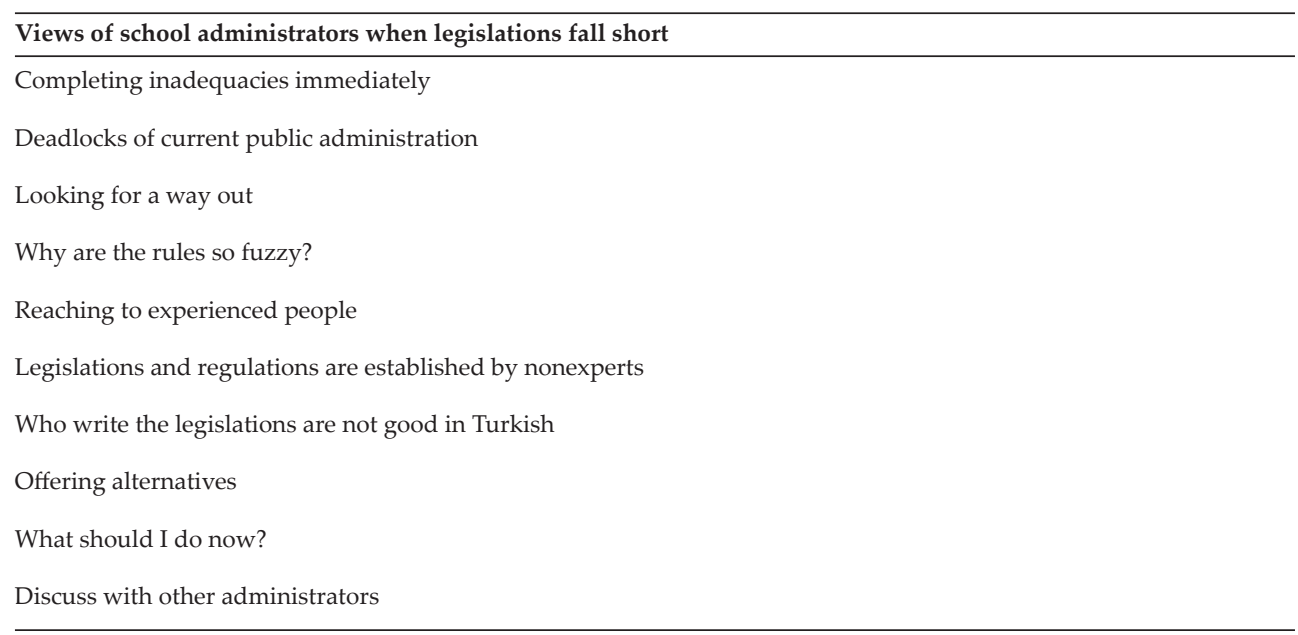

Table 3. Views of school administrators when legislations fall short.

\begin{tabular}{ll}
\hline Feelings and reactions of school administrators when legislations fall short \\
\hline Will I hurt or get hurt & Calling an experienced administrator \\
Stalemated & Choose to communicate \\
Negative & Try to reach true information \\
Wretched & Research \\
Conflict & Get angry \\
Troublesome & Look for different applications \\
Distrust & Be sorry \\
Calm complain & Try to be patient and e-mail to the superiors \\
Comfortable & Make suggestions to superiors \\
Interrogative & Try to find solutions \\
Inadequate & Read over and over again until brief understanding \\
Helpless &
\end{tabular}

Table 4. Findings about the feelings and reactions of school administrators when legislations fall short.

When participant school administrators encounter initiative-requiring situations, they stated that they look for other sources available in case legislations and regulations fall short. Similarly, other reactions include calling an experienced administrator, doing research, and looking for different applications. 


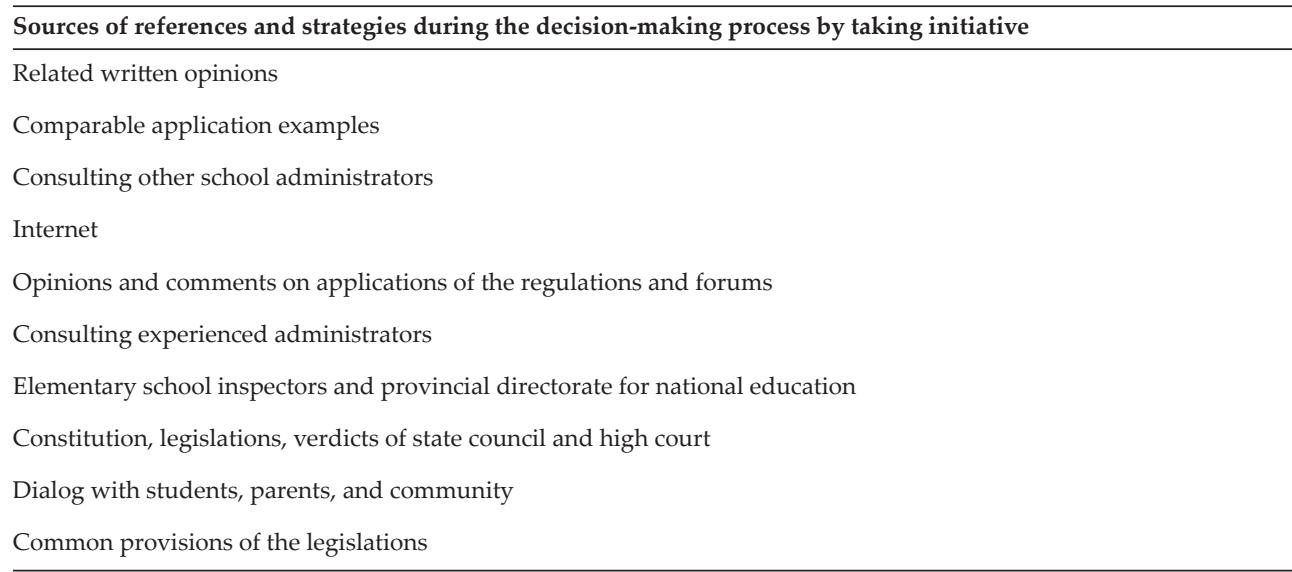

Table 5. Findings about the sources of references and strategies during the decision-making process by taking initiative.

\subsection{Findings about the principles, values, and ethical frames when school administrators take initiative}

Principles, values, and ethical frames when school administrators take initiative can be summarized as common interest, social responsibility, rationality both in thinking and acting, justness, priorities, and accountability (Table 6).

S.A.1. "... What I desire is that I want other people to see what I see and understand. In other words, if I decide on something, I do so for the everyone's good..."

S.A. 5. "...Principally, I try not to make people say the school administrator protects someone because of his or her political views. I am sensitive about that. If I make decisions that I can account for, there is no problem though..."

S.A. 9. ".... Now that this is a public institution. It has objectives and we all have to work for them. I have to make my school successful. I have to satisfy my students' academic expectations. Just as parents, teachers and personnel. I pay attention on achieving these goals..."

\subsection{Findings about the outcomes of the initiatives taken by school administrators}

Table 7 presents the codes for outcomes of the initiatives taken by school administrators. Identified by analyzing the data, these codes are grouped in two as positive and negative outcomes. It can be derived from the codes that taking initiative improves administrators' leadership skills and administrative competence, enhances professional development and decision-making skills, enables restructuring the realm of authority, reinforces organizational structure, and increases self-esteem with self-confidence.

When negative outcomes of taking initiative are considered, administrative and organizational elements were noticed as the worrying outcomes. Receiving warnings on exceeding 


\section{Principles, values, and ethical frames when school administrators take initiative}

Public interest

Student and teacher interests

Justness

Applicability for everyone

Objectivity

School success

School priorities

Not looking for personal interest

Not discriminating the political views

Positive thinking

Accountability

General purposes of education and training

Rationality

Efficiency

Goal oriented

Student satisfaction

Consistency

Human oriented

Teacher psychology

Social values

General satisfaction

Table 6. Findings about the principles, values, and ethical frames when school administrators take initiative.

\section{A. Positive outcomes}

Advancement in administrational competence

Expansion of authority

Advancement in persuasion

Advancement in problem-solving skills

Improved organizational commitment of teachers

Advancement in crisis management

Improvement in flexible thinking

Raise of accountability

Division of authority

More aggressiveness for future decisions

Improvement of perspective

Alienation from conventional thinking

Accelerated personal and professional improvement

Inclining from administering to leadership 
Effective use of informal power sources

Courageousness in new challenges

Ability of quick decision-making despite bureaucracy

Identification with the school

Enhanced self-esteem and creativity

Research oriented

Increasing attempts to communication and interaction

Improved prestige of the administrator

Expansion of tolerance

Sense of success

Realizing abilities

Thinking human oriented and product oriented

Job satisfaction

Solution-oriented thinking

Transparent and principled working

Finding solutions to teachers' expectations

Advancement in authority and control

Effective use of time

Learning to benefit from legal blind spots

Get free of being a watchdog of the legislation

Creating a vision

Un-mechanization

Team work

\section{B. Negative outcomes}

Going beyond the realm of authority

Limited effects of initiatives

Unbalance between authority and responsibility

Being left alone when taking responsibility

Consequences of taking risks

Abuse of good faith

Be stuck in a difficult situation in formal inspections

Be subject to reactions of superiors

Stress and anxiety

Additional works

Increased professional exhaustion

Continuous research of legal grounds

Increase of nonchalance because of negative effects of initiatives

Concerns on losing control

Be sick of numerous inspections and receive warnings

Table 7. Findings about the outcomes of the initiatives taken by school administrators. 
their authority, concerns about the unstable situation between risk taking and accountability, thoughts about dysfunctionality of initiatives on organizational change, and concerns about the risk of being investigated are situations discouraging school administrators to take initiative. Even though proficient and willing in taking initiative, discouraging situations like these may probably cause professional exhaustion and, consequently, lower tendency to take initiative.

\section{Discussion}

Initiative is a concept that helps administrators to perceive the mechanisms in organizational structure and administrative functioning. It also supports administrators to comprehend the nature of democratic decision-making mechanisms [36]. However, research results indicated that school administrators were left alone in the process of initiative-taking processes, and their capacity to take initiative was unable to influence the school as a whole. Thus, initiative taking was unable to support creativity and foresight, but rather it appears to support bureaucratic rationalization and pragmatism.

The findings of the study primarily indicated that school administrators who participated in the study did not use initiative to reach organizational goals, active decision-making to solve organizational problems, and the will to make decisions that were described in the literature [7-10, 13]. Rather, they used initiative in situations that involved limited risks in order to get recognition and avoid supervision and do not require much astuteness and creativity. These initiative behaviors reflected the tendency of being momentary and having pragmatic thinking [7, 8]. School administrators indicated that they had gone through intensive negative feelings such as insecurity, conflict, anxiety, incompetency, fear of being victimized, and worried about going under investigation.

School administrators used initiative to a limited extent in areas like organizational change and daily routines rather than transforming bureaucratic behavior. Akın's [3] findings support the findings of this study. Akın [3] also found that school administrators took small-scale initiatives, initiative taking was more likely to increase with experience, and areas for initiative were improving physical infrastructure and providing resources. Akın's [3] findings also indicated that school administrators were likely to take initiative that are limited to areas such as instructional leadership, and administrators who took initiatives likely feel threats of facing sanctions.

One of the most interesting findings of this study was the negative feelings of school administrators such as insecurity, conflict, anxiety, incompetency, fear of being victimized, and worried about going under investigation when they found themselves in initiative-taking circumstances. Initiative taking can transform schools' hierarchical and bureaucratic functioning into strategic ones and enables the use of the dynamics to take action. However, negative feelings mentioned earlier are likely to prevent the school administrators to take initiative even when they have a potential. From this perspective, it is clear that initiative taking is not only an individual behavior but also an organizational and administrative behavior [37]. Administrative behavior is not limited to structural and institutional components, but it includes cultural and individual components. Therefore, it is important to reveal the individual will to integrate organization in school culture. Values and principles that school administrators consider while taking initiative were the public interest, institutional benefits, fairness, 
objective thinking, and human orientation. These values and principles are likely to contribute to organizational values and create an ethical frame in schools.

Circumstances where school administrators used initiative resulted in upsetting the balance of authority and responsibility by increasing responsibility and administrative skills, but it was not taken positively and threatened for sanctions and use of power, transforming from legal authority to leadership. However, this is limited by the higher level of bureaucracy, since hierarchical and bureaucratic supervision was implemented. As Hakanen et al. [21], Binnewies et al. [20], and Bracci [14] argued, the use of initiative appears and may be effective in organizational models and administrative approaches when power distance is diminished. School administrators in this study experienced centralized structure and functioning. Thus, they felt limitations imposed on them such as the requirement to cope with difficult situations, systematic and methodical thinking, generating solutions and suggestions, finding alternatives, references to a rich and in depth thinking, and being proactive.

When all results are taken into account, in order to improve school administrators' initiativetaking behaviors and expanding the areas for initiative taking, local ministry of education directorates could collaborate with universities to organize workshops and seminars. Encouraging school administrators to pursue graduate degrees such as masters and doctorate degrees might help them develop leadership behavior and likely to improve areas of influence rather than areas of authority. This could help them to improve their competencies in initiative-taking behavior. Further studies are required to increase school administrators' authority and responsibility at the ministry level. Decentralization and school-based management efforts might also help improve the structure for widening school administrator's perspective to take initiative. Mentoring might help at the school level by matching more experienced school administrators with inexperienced school administrators. Finally, the best practices of initiative-taking behavior might be archived and shared with school administrators in digital resources and blogs.

The best practices for organizations to structure their internal dynamics and capacities, active information management, organizational confidence, and collaborative work culture could be empowered by the ability of taking initiative [49]. Initiative could also be considered as a factor that paves the way for an administrative paradigm that transforms conventional hierarchy, disrupts the authority, and moves centralization toward localism.

Taking initiative is a significant element of leadership when approached from the perspectives of cognitive structure, beliefs, values, affective traits [19], and dynamic relations, providing autonomy, balancing power, empowering self-control [24], self-sufficiency, organizational social behavior, and positive relationship approach [38]. Initiative is an expression of an influence, "a real and recognized authority," rather than a legally described authority. In other words, it is an area of impact and power that is reflected from the area of skills and abilities, instead of an authority resulting from a hierarchical position. It is the transfer of formal authority to organizational structure in order to empower authority in the administrative sense. Distribution of formal authority and delegation could support organizations in taking initiative. Initiative is the capacity to make a decision and spring into action at a moment and situation where the area of control is expanded. It facilitates horizontal communications and coordination in organizational structure. Initiative is the creator of a real and recognizable area of power outside the formal authority. The ability to create projects, willingness to take control, risk and crisis management, 
priorities, knowledge, communication, psychological organizational contract, performance evaluation, and supporting multiple managements are among the outcomes of taking initiative. Initiative taking includes the factors of entrepreneurship, active personality, self-motivation, internal motivation, active goal setting, planning and time management skills, overcoming obstacles and emotion management, persuasive and credible communications, creativity and innovation in personal competence, and quality dimension in addition to the administrative and organizational dimensions [39]. Initiative is a concept related to authentic responsibility, proactive personality, changing needs and roles, transformative leadership, distributive leadership, organizational change, organizational behavior, social dynamism, cultural integration, professionalization, and social and cultural capital [40,41].

Workers go about their daily lives with high expectations. Active entrepreneurship and initiative-taking traits are significant qualities for organizational change beyond personal benefits and psychological satisfaction they promote. It is reinforcement of active behavior. It is improvement of creative thinking and problem-solving competencies and an effort to behave work oriented [38]. Today, initiative is a theoretical and application framework for the efforts to develop important administrative reform and strategies, specific goals, and school plans that are significant for schools in developing school-based and internal dynamics of the school that are specific to that particular school and the potential of the school [42]. Autonomy could be considered as an outcome of initiative taking and developing behavior as well [43]. Initiative-taking school administrators could facilitate teacher participation, loyalty in the school, school productivity, and academic success and focus more on teaching and learning. Administrators could perceive initiative-taking skills as an action that realizes school development plans [44]. Initiative is a factor that supports organizational learning, frees an area of action, enforces organizational operations and increases the capacity, renders school administrator more powerful than central administrators, and supports and functionalizes decisionmaking mechanisms of school administrator with respect to change management [45-50].

Based on the above discussion, it could be inferred that the efforts of participating school administrators on school-based decision-making and acting, which could be considered as leadership characteristics beyond their formal authority, were insufficient. Participating school administrators in the current study were able to use their initiative-taking actions under limited conditions and situations. Thus the phenomena such as organizational change, organizational learning, designing an autonomous administrative area by transforming institutional internal dynamics into a unique strategy, and enforcing organizational capacity could not be realized. The fact that school administrators were concerned about the consequences of the situations where they decide by initiative taking and act accordingly results in preventing the improvement of their proactive personality traits and obscures their psychological contract variables with the organization and creative and innovative thinking skills. The related circumstances could diminish internal motivation of school administrators in taking action even in necessary and predictable conditions. It could lower self-efficacy perception. It could force them to fall behind their leadership role. And the most important, it could neutralize their efforts to refer to references that could expand their area of initiative. Based on the results of the present study, it could be beneficial to design and implement studies that would structure professional cooperation and university-specialist-school collaboration to support 
the abilities of school administrators in the management of initiative-taking situations and their results. It is important to engage in planning that would reinforce the coping strategies of school administrators with the situations that were not explained in legal manuscripts in addition to the decisions taken by the administrators in the higher hierarchy and to determine the references in the academic dimension. For the researchers, it could be recommended to design studies that aim to develop school-based administrative models, analyze initiative and leadership variables comparatively, and determine the perceptions of central and local organization administrators on school administrators and initiative taking.

\section{Author details}

İlknur Şentürk

Address all correspondence to: ilknurkokcu@gmail.com

Department of Educational Sciences, Faculty of Education, Eskişehir Osmangazi University, Eskişehir, Turkey

\section{References}

[1] Şişman M, Turan S. Eğitimde yerelleşme ve demokratikleşme çabaları. Teorik bir çözümleme. Kuram ve Uygulamada Eğitim Yönetimi. 2003;34:300-315

[2] Oxford Dictionaries. [Internet]. Initiative. Available from: https://en.oxforddictionaries. com/definition/initiative [Accessed: Jan 3, 2016]

[3] Akın U. Örgüt ve Yönetimde İnisiyatif Alma. Ankara: Pegem Akademi Yayıncılık; 2012

[4] Belschak FD, Hartog DD. Personal initiative, commitment and affect at work. Journal of Occupational and Organizational Psychology. 2007;80:601-622

[5] Bledow R, Frese M. A situational judgment test of personal initiative and its relationship to performance. Personnel Psychology. 2009;62:229-258

[6] Dreu D, Carsten KW, Aukje N. Self-interest and other-orientation in organizational behavior: Implications for job performance, prosocial behavior, and personal initiative. Journal of Applied Psychology. 2009;94(4):913-926

[7] Frese M, Fay D. Personal initiative: An active performance concept for work in the 21st century. Research in Organizational Behavior. 2001;23:133-187

[8] Frese M, Fay D. The concept of personal initiative: An overview of validity studies. Human Performance. 2001;14(1):97-124

[9] Frese M, Fay D, Hilburger T, Leng K, Tag A. The concept of personal initiative operationalization reliability and validity in two German samples. Journal of Occupational Psychology. 1997;70:139-161 
[10] Frese M, Garst H, Fay D. Making things happen. Reciprocal relationships between work characteristics and personal initiative in a four-wave longitudinal structural equation model. Journal of Applied Psychology. 2007;92(4):1084-1102

[11] Yücel Z. İlköğretim okulu yöneticilerinin yetki kullanımında ve yetki devrinde yaşadıkları sorunlar [thesis]. Denizli, Turkey: Pamukkale University, Deparment of Social Sciences; 2006

[12] Keser Z. Ortaöğretim okul müdürlerinin yetki ve sorumluluklarını kullanma derecelerinin belirlenmesi [thesis]. Gaziantep, Turkey: Gaziantep University, Deparment of Social Sciences; 2007

[13] Frese M, Kring W, Soose A, Zempel J. Personal initiative at work. Differences between east and west Germany. Academy of Management Journal. 1996;39:137-163

[14] Bracci E. Autonomy, responsibility and accountability in the Italian school system. Critical Perspectives on Accounting. 2009;20:293-312

[15] GutierrezARC, Guerrero AB. Education and entrepreneurship: Educating in the new competence of autonomy and personal initiative. International Journal of Learning. 2011;18(8): 237-247

[16] Van Zandt CE. Professionalism: A matter of personal initiative. Journal of Counseling \& Development. 1990;68(3):243-245

[17] Aypay A, Şekerci M. İlköğretim okulu yöneticilerinin yönetim becerileri ile grup etkililiği arasındaki ilişki. Kuram ve Uygulamada Eğitim Yönetimi, Educational Administration: Theory and Practice. 2009;15(57):133-160

[18] Goerdel HT. Taking initiative: Proactive management and organizational performance in networked environments. Journal of Public Administration Research and Theory. 2006;16(3):351-367

[19] Fischbacher U, Bruttel L. Taking the initiative. What characterizes leaders? European Economic Review. 2013;64:147-168

[20] Binnewies C, Ohly S, Sonnentag S. Taking personal initiative and communicating about ideas: What is important for the creative process and for idea creativity? European Journal of Work and Organizational Psychology. 2007;16(4):432-455

[21] Hakanen JJ, Perhoniemi R, Toppinen-Tanner S. Positive gain spirals at work: From job resources to work engagement, personal initiative and work-unit innovativeness. Journal of Vocational Behavior. 2008;73:78-91

[22] Warr P, Fay D. Age and personal initiative at work. European Journal of Work and Organizational Psychology. 2001;10(3):343-353

[23] Demirel Y, Karadal HY. Örgüt kültürünün örgüt içi bireysel becerilerin kullanımına etkisi üzerine bir araştırma. Süleyman Demirel Üniversitesi İktisadi ve İdari Bilimler Fakültesi Dergisi. 2007;12(3):253-270 
[24] Ambos TC, Andersson U, Birkinshaw J. What are the consequences of initiative-taking in multinational subsidiaries? Journal of International Business Studies. 2010;41:1099-1118

[25] Çetin F, F1kırkoca A. Rol ötesi olumlu davranışlar kişisel ve tutumsal faktörlerle öngörülebilir mi? Ankara Üniversitesi SBF Dergisi. 2009;65(4):42-66

[26] Fidan T. Ankara ili ilköğretim okulu yöneticilerinin örgütsel özerkliğe ilişkin görüş ve önerileri [thesis]. Ankara, Turkey: Ankara University, Deparment of Educational Sciences; 2007

[27] Frohman AL. Igniting organizational change from below: The power of personal initiative. Organizational Dynamics. 1997;25(3):39-53

[28] Giray N. Okul yöneticilerinin yönetimsel karar verme ve problem çözme yeterlikleri [thesis]. İstanbul, Turkey: Yeditepe University, Deparment of Social Sciences; 2006

[29] Hacımustafaoğlu MF. Personel güçlendirme algılarının bireysel yaratıcılığa etkisi ve otel işletmelerinde bir uygulama [thesis]. İstanbul, Turkey: Marmara University, Department of Social Sciences; 2008

[30] Merriam S B. S Turan, (Translation editor). Nitel Araştırma: Desen ve Uygulama İçin Bir Rehber. Ankara, Turkey, Nobel Yayıncllık; 2013

[31] Berg L B, Lune H. H Aydın, (Translation editor). Sosyal Bilimlerde Nitel Araştırma Yöntemleri. Konya, Turkey, Eğitim Yayınevi; 2015

[32] Glesne C. A Ersoy, P Yalçınoğlu, (Translation editors). Nitel Araştırmaya Giriş. Ankara, Turkey, Anı Yayıncılık; 2012

[33] Yıldırım A, Şimşek H. Sosyal Bilimlerde Nitel Araştırma Yöntemleri. Ankara, Turkey: Seçkin Yayınevi; 2008

[34] Patton MQ. How to Use Qualitative Methods in Evaluation. USA: Sage Pub; 1987

[35] Miles MB, Huberman MA. An Expanded Sourcebook Qualitative Data Analysis. London: Sage; 1994

[36] Cameron TJ. Managers: Part of the Problems? Changing How the Public Sector Work. USA: Greenwood Press; 1999

[37] Dörrenbächer C, Geppert M. A micro-political perspective on subsidiary initiative-taking: Evidence from German-owned subsidiaries in France. European Management Journal. 2009;27(2):100-112

[38] Lantz A, Andersson K. Personal initiative at work and when facing unemployment. Journal of Workplace Learning. 2009;21(2):88-108

[39] Frese M, Hass L, Friedrich C. Personal initiative training for small business owners. Journal of Business Venturing Insights. 2016;5:27-36

[40] Deichmann D, Ende J. Rising from failure and learning from success: The role of past experience in radical initiative taking. Organization Science. 2014;25(3):670-690 
[41] Thompson JA. Proactive personality and job performance: A social capital perspective. Journal of Applied Psychology. 2005;90(5):1011-1017

[42] Jong T, Griffiths C. Developing the capacity of Australian secondary schools to cater for students with high support needs in mental health and wellbeing an effective school case management resource. School Psychology. 2008;29(1):29-38

[43] Strunk KO, Marsh JA, Bush-Mecenas SC, Duque MR. The best laid plans: An examination of school plan quality and implementation in a school improvement initiative. Educational Administration Quarterly. 2016;52(2):259-309

[44] Honig HM, Rainey LR. Autonomy and school improvement: What do we know and where do we go from. Educational Policy. 2012;26(3):465-495

[45] Honig MI. No small thing: School district central office bureaucracies and the implementation of new small autonomous schools initiatives. American Educational Research Journal. 2009;46(2):387-422

[46] Hahn VC, Frese M, Binnewies C, Schmitt A. Happy and proactive? The role of hedonic and eudaimonic well-being in business owners' personal initiative. Entrepreneurship Theory and Practice, Special Issue: The Heart of Entrepreneurship. 2012;36(1):97-114

[47] JH MM, Schumacher S. Research in Education: Evidence-based Inquiry. USA: Pearson; 2010

[48] Turan S, Yücel C, Karataş E, Demirhan G. Okul müdürlerinin yerinden yönetim hakkındaki görüşleri. Uşak Üniversitesi Sosyal Bilimler Dergisi. 2010;3(1):1-18

[49] Yu-Yuan Hung R, Ya-Hui Lien B, McLean GN. Knowledge management initiatives, organizational process alignment, social capital, and dynamic capabilities. Advances in Developing Human Resources. 2009;11(3):320-333

[50] Schraub EM, Michel A, Shemla M, Sonntag K. The roles of leader emotion management and team conflict for team members' personal initiative: A multilevel perspective. European Journal of Work and Organizational Psychology. 2014;23(2):263-276 